\title{
METARADIOPHRYA EGYPTIACA N.SP. AN ASTOMATOUS CILIATE FROM THE ALIMENTARY CANAL OF ALLOLOBOPHORA CALIGINOSA (ANNELIDA: OLIGOCHAETA).

\author{
By \\ AHMED HAMDY NIGM
}

Department of Zoology, Faculty of Science, Ain Shams University, Cairo 11566, Egypt (Correspondence: Ahmednigm@sci.asu.edu.eg)

\section{Abstract}

In this study, 639 of Allolobophora caliginosa were collected from different regions of Nile Delta of Egypt. Metaradiophrya egyptiaca n. sp. was recorded in intestinal worms from Bajour (Monoufia Governorate) only. Ciliate species ranged in size from $100-137 \mu \mathrm{m}(125.7 \pm 9.9 \mu \mathrm{m})$ in length $\& 57-88 \mu \mathrm{m}(72.5 \pm 10.7)$ in width. Macronucleus is long, band-shape, varied between $71-$ $106 \mu \mathrm{m}(92.8 \pm 10.2 \mu \mathrm{m})$ in length $\times 5.6-10.3 \mu \mathrm{m}(7.3 \pm 1.5 \mu \mathrm{m})$ in width. Ciliate has 2 rows of contractile vacuoles on both side of macronucleus, each row of 4-6 vacuoles. There were 75-84 kineties on body dorsal side and 56-60 kineties on ventral one. The 58 ectoplasmic fibers restricted in anterior ventral depressed region, from which 12-13 ones end on ectoplasm left clear area and 9 fibers from distal end of the right shaft.

Keywords: Metaradiophrya egyptiaca, Allolobophora caliginosa, Astomatous ciliate, Egypt.

\section{Introduction}

Earthworms (Annelida, Oligochaeta) are recognized to harbor symbiotic astomatous ciliates (order Astomatida) in intestines (Pitelka, 2013). These ciliates lack mouth and covered by uniform cilia; and some astomes have suckers, but others use various hooks or barbs. Genus Metaradiophrya belongs to class Oligohymenophorea, subclass Hymenostomatia, order Astomatida \& family Radiophryidae (Lynn, 2008). Heidenrich (1935) established genus Metaradiophrya with 2 Hoplitophrya species Stein, 1860, H. lumbrici, and $H$. falcifera Stain, 1861. Genus Metaradiophrya is characterized by its anterior ventrally placed attaching apparatus consisted of a curved ventrally directed central spine (hook), continuous with a larger shaft lying on the right side of the cell body. Also, some species have a smaller shaft which is attached to the central spine and laid on the left side of the cell body. Many ectoplasmic fibers are connected to attaching apparatus for supporting (collectively referred to as cytoskeleton). The number and distribution of ectoplasmic fibers were constant and species character (De Puytorac, 1954). Several Metaradiophrya species described as M. asymmetrica (Beers, 1938); $M$. chlorotica, M. wenrichi (Williams, 1942);
M. lituiformis (Georgevitch, 1941); M. hovassei, M. varians, M. gigas, M. heidenreichi and M. bifulta (De Puytorac, 1954); M. gardneri (Rees, 1961); M. pheretimi (Bhandari, 2012) \& M. simplex (Fokam, 2012). De Puytorac (1954) gave a monograph on the astomatous ciliates, with wide morphological and taxonomic data of Metaradiophrya and diagnostic descriptions for known species. Molecular techniques were used in exploring genetic diversity and phylogenetic position of subclass Astomatia (Fokam et al, 2011), but these techniques for specific astomatous ciliates identification not yet used.

In Egypt, insufficient studies were done on the endosymbiotic ciliates of annelids, and the present study aimed to explore biodiversity of the ciliates infecting the Egyptian Annelids, especially Oligochaetes.

\section{Materials and Methods}

Allolobophora caliginosa worms were collected from Bajour (Menoufia Governorate), Marg (Qalyobia Governorate), Embaba (Giza Governorate) and Magaga (Menia Governorate). Worms were trapped by a labeled plastic container with some local damp soil and immediately transport to laboratory. They were put in a sieve under running tap water to remove attached debris and soil grains. Each one was cut transversely into 
small parts in clean dish; each part was dissected on clean glass slide with a drop of normal saline solution $(0.8 \%)$, covered and microscopic examination. After examination, slides were semidried and fixed for 20 min. in Schaudin's solution (saturated aqueous solution of mercuric chloride \& few drops of glacial acetic acid). A group of slides were washed in ethanol to remove excess mercuric chloride, transferred to $3 \%$ an iron alum solution for $3 \mathrm{hrs}$ and stained with Heidenhain's haematoxylin stain (20min.), differentiated in $1 \%$ iron alum solution, washed in distilled water, dehydrated, cleared in xylene and mounted in Canada balsam. Another group of slides were stained in haematoxylin stain for 30min., transferred to a tap water for one minute, and then dipped in eosin stain. Silver line system was revealed by the wet silver nitrate method (Foissner, 2014). Photomicrographs were taken by a Kodak digital camera (model 1450Z) attached to a compound microscope.

\section{Results}

From 639 totally collected worms, 44 ones were from Bajour (Menoufia $\mathrm{G}$,), of which 12 ones were infected with Metaradiophrya egyptiaca $\mathrm{n}$. sp. This species was very active and usually found in the anterior two thirds of the host's intestine.

General morphology: Metaradiophrya egyptiaca n. sp. has a broad short and dorsoventrally flattened body, which was slightly widest at the middle portion (Fig. 1 A). The anterior extremity was more or less pointed while the posterior one round or truncated in a plane that was oblique on body longitudinal axis. The dorsal side was convex and the ventral one was more or less flattened (Fig. 1A). Laterally, the body thickness gradually increased from the posterior extremity to anterior one. Ventrally, an anterior concavity formed a depression, immediately below the attaching apparatus, where the cilia were beat independently creating circular waves. This region was often closely applied to the host's tissue to fix ciliate into the intestinal wall. Body length varied bet-ween
$100 \mu \mathrm{m} \& 137 \mu \mathrm{m}(125.7 \pm 9.9 \mu \mathrm{m})$, but width varied between $57 \mu \mathrm{m}$ \& $88 \mu \mathrm{m} \quad(72.5$ $\pm 10.7 \mu \mathrm{m})$ on the body modally. Some cases of cellular division were observed.

The cilia were slightly longated at the cell posterior part $(11 \mu \mathrm{m})$ than those in the anterior one, generally, did not exceed $7 \mu \mathrm{m}$; besides, the cilia were shorter on the ventral surface than those on the dorsal one. By observing the active ciliate, the cilia synchronous waves of strokes originated in the body lower right side as an oblique wave (wave direction form an angle with body longitudinal axis) that propagated upward on the upper left side (Fig.1B).

The ciliate moved in saline media either by rotating forward its longitudinal axis as counterclockwise (Fig.1Fa) or progressing on its ventral side; of body anterior part up forming an angle with movement direction of (Fig. 1Fb). Macronucleus was long, bandshape, narrow and some- what irregular in outline (Fig. 2A), varied between $71 \mu \mathrm{m} \&$ $106 \mu \mathrm{m}(92.8 \pm 10.2 \mu \mathrm{m}) \times 5.6-10.3 \mu \mathrm{m}(7.3 \pm$ $1.5 \mu \mathrm{m})$ in width. Sometimes, macronucleus formed a kind of spiral path along the animal longitudinal axis (Fig. 2B). The micronucleus was hardly seen, being spherical, $2.6 \mu \mathrm{m}$ in diameter for an individual ciliate $130 \mathrm{l} 88 \mu \mathrm{m}$, situated on the ciliate lower right side adjacent to macronucleus (Fig. 1 A \& Fig. 2 A).

The ciliate has two rows of contractile vacuoles arranged on either side of macronucleus. Each row composed of 4-6 vacuoles more or less straightened in course (Fig. $1 \mathrm{~A} \&$ Fig. 2A). Average vacuoles number in a single ciliate was 9 (12-7vacuoles), smaller ones were about $2.7 \mu \mathrm{m}$ in diameter and the larger ones reached $8 \mu \mathrm{m}$.

Attaching apparatus (cytoskeleton) was typical in general form for generic characterization. It formed an inverted asymmetrical $\mathrm{V}$ shape, where the shaft, lied on body right side was much longer than central ventrally curved spine prominently on ciliate anterior medial line (Fig. 1A). This system was easily stained by $\mathrm{H} \& \mathrm{E}$ (Fig. 2D). The shaft 
size varied between $17 \mu \mathrm{m} \& 28 \mu \mathrm{m}(22 \pm 3)$ in length. Central spine varied between $8 \mu \mathrm{m}$ $\& 12 \mu \mathrm{m}(10.2 \pm 1.2)$ in length with an irregular diameter; reached $2.5 \mu \mathrm{m}$ in its width. No evidence of an articulation between the spine and shaft. On left side of central spine was an area of ectosarc with neither any ectoplasmic fibers nor kineties (Fig. 1C, D \& Fig.2 E). This area was up to $9 \mu \mathrm{m}$ long with sometimes appearance of second short shaft connected to the attaching apparatus.

There were 75-84 kineties on the dorsal side and 56-60 kineties on body ventral one, with a total number of 131-144 kineties around the body. Intervals between kineties on ventral side was asymmetrical, these intervals between the kineties on the ciliate left side were greater than those on right side, $1 \mu \mathrm{m} \&$ $0.7 \mu \mathrm{m}$ respectively, (Fig. 1E). On dorsal side, the intervals between kineties were alike and more closely spaced than intervals of kineties on ventral one, $0.6 \mu \mathrm{m}$ (Fig. 2C). Moreover, the dorsal kineties on anterior region were generally directed toward the right where they converge slightly. Ventral kineties on left side turned more anteriorly to the right direction in course mid line to end around attachment apparatus (Fig.1C).
Starting from the distal end of right shaft to the hook base about 30-41 kineties originated ventrally, but dorsally were 55-60 ones. In the left clear area, 9-14 kineties originated ventrally and 20-24 ones originated dorsally (Fig.1C). Posteriorly, dorsal and ventral rows of kineties showed little or no convergence toward the midline but end independently along truncated posterior border (Fig. 2E).

Ectoplasmic fibers, supported the attaching apparatus, were mainly restricted on anterior ventral depression region (Fig. 1D \& Fig. 2F). The longest ones were located on the depression left side, and gradually shorten towards right side. Ectoplasmic fibers were beside to the ciliary rows and nearly parallel with them. On the ciliate right side, the fibers were closely packed than those on the left side. The number of fibers was 58, which course forward to attachment apparatus, from which 12-13 ones end on ectoplasm left clear area. Dorsally, 9 fibers originated from the right shaft distal end that course posteriorly for a certain distance (Fig. 1D \& Fig. 2F). Generally, ectoplasmic fibers supported right shaft of distal end were the thickest.

Table 1: Comparison between Metaradiophrya egyptiaca n. sp. and other related species.

\begin{tabular}{|c|c|c|c|c|c|c|}
\hline \multirow{2}{*}{ Species } & \multirow{2}{*}{$\begin{array}{c}\text { Body Dimen. } \\
(\mu \mathrm{m})\end{array}$} & \multirow{2}{*}{$\begin{array}{l}\text { Contract. } \\
\text { vacuoles }\end{array}$} & \multicolumn{2}{|c|}{ Attaching apparatus } & \multirow{2}{*}{$\begin{array}{l}\text { Ectoplas. fibers } \\
\text { (ventral) }\end{array}$} & \multirow{2}{*}{ Kineties of body } \\
\hline & & & Shaft $(\mu \mathrm{m})$ & Spine $(\mu \mathrm{m})$ & & \\
\hline $\begin{array}{c}\text { Metaradiophrya } \\
\text { egyptiaca } \\
\text { Present work }\end{array}$ & $\begin{array}{c}125.7 \\
\mathrm{X} \\
72.5 \\
\end{array}$ & $\begin{array}{c}4-6 \\
\text { each side }\end{array}$ & $22 \pm 3.1$ & $10.2 \pm 1.2$ & $57-58$ & $\begin{array}{c}(131-144) \\
75-84 \text { dorsal } \\
56-60 \text { ventral }\end{array}$ \\
\hline $\begin{array}{c}\text { M. gigas } \\
\text { De Puytorac, } 1954\end{array}$ & $\begin{array}{c}550 \times \\
165 \\
\end{array}$ & $\begin{array}{l}10-12 \\
\text { each side }\end{array}$ & $40 \times 3.5$ & $17 \times 4$ & 65 & $\begin{array}{c}(137) \\
66 \text { dorsalx71 ventral }\end{array}$ \\
\hline $\begin{array}{c}\text { M. lumbrici } \\
\text { De Puytorac, } 1954\end{array}$ & $150 \times 75$ & $\begin{array}{c}5-9 \\
\text { each side }\end{array}$ & $25-30 \times 2.5$ & $10-11$ & $\begin{array}{c}62 \\
\text { longer in med-line }\end{array}$ & $\begin{array}{c}(155) \\
84 \text { dorsalx71 ventral }\end{array}$ \\
\hline $\begin{array}{c}\text { M. heidenreichi } \\
\text { De Puytorac, } 1954\end{array}$ & $195 \times 75$ & --- & $35 \times 2.6$ & $12-13$ & $\begin{array}{c}58 \text { asymmetric } \\
\text { arrangement }\end{array}$ & $\begin{array}{c}(138) \\
75 \text { dorsalx63 ventral }\end{array}$ \\
\hline $\begin{array}{l}\text { M. asymmetrica } \\
\text { Beers, } 1938\end{array}$ & $\begin{array}{l}115-150 \\
\times 55-70\end{array}$ & $\begin{array}{c}3-6 \\
\text { each side }\end{array}$ & $30 \times 2$ & $\begin{array}{c}10 \\
\text { fused with shaft }\end{array}$ & $25-30$ & $\begin{array}{c}(100-120) \\
\text { with interval } 1 \mu \mathrm{m}\end{array}$ \\
\hline $\begin{array}{c}M \text {. simplex } \\
\text { Fokam, } 2012\end{array}$ & $\begin{array}{r}115-223 \\
\times 52-150\end{array}$ & $\begin{array}{l}8-23 \text { in } \\
\text { two rows }\end{array}$ & $44-70$ & No spine & 74 & $\begin{array}{l}\text { 57-102 dorsal } \\
46-70 \text { ventral }\end{array}$ \\
\hline $\begin{array}{c}\text { M. wenrichi } \\
\text { Williams, } 1942\end{array}$ & $\begin{array}{c}76-152 \\
x \\
29-58\end{array}$ & ----- & $\begin{array}{l}\text { similar to } \\
M \text {. } \\
\text { lumbrici }\end{array}$ & $\begin{array}{l}\text { similar to } \\
M \text {. } \\
\text { lumbrici }\end{array}$ & ---- & ---- \\
\hline
\end{tabular}

\section{Taxonomic summary}

Type host: Allolobophora caliginosa (Annelida: Oligochaeta).

Type locality: Hosts were collected from Bajour (Menoufia Governorate). 30²5'54.5" $\mathrm{N} 31^{\circ} 02^{\prime} 08.5^{\prime \prime} \mathrm{E}$

Prevalence: $12 / 639(1.8 \%)$

Site of infection: Intestine.
Etymology: Species name egyptiaca derived from the country name, Egypt.

Type specimens: Permanent prepared slides deposited in Parasitological Collection, Zoology Department, Faculty of Science, Ain Shams University, Cairo 11566, Egypt. 


\section{Discussion}

In this study, Metaradioprhya egyptiaca $\mathrm{n}$. sp. was found in a population of Allolobophora caliginosa. The morphological characteristics determined its generic name, coincided with those characterizing this genus (Heidenrich, 1935; Hovasse, 1945; De Puytorac, 1954), ciliate with the prominent anterior inverted $\mathrm{V}$-shaped attachment apparatus.

The attaching apparatus composed of a curved ventrally directed central spine or hook, which was a part of a larger shaft laying on the cell body the right side. In some species, apparatus included a smaller second shaft attached to the central spine and lying on cell body left side.

The present species was similar to $M$. gigas, M. lumbrici, M. heidenreichi, M. asymmetrica, M. pheretimi, M. gardneri, M. simplex, $M$. wenrichi and $M$. lituiformis without the second shaft, which was well developed on the left side of other species, e.g. M. varians, M. bifulta and M. hovassei. Within the range of size of the present parasite were $M$. lumbrici Heidenreich $(150 \times 75 \mu \mathrm{m})$, M. heidenreichi De Puytorac $(195 \times 75 \mu \mathrm{m}), M$. asymmetrica Beers (115-150x55-70 $\mu \mathrm{m})$ and $M$. wenrichi Williams (76-152x29-58 $\mu \mathrm{m})$.

Heidenreich (1935) described M. lumbrici from Lumbricus rubellus and Eisenia foetida and reported that hook articulated with the slightly curved right half of the attaching apparatus. But, in the present study, no evidence was observed for any kind of movement to hook with the right shaft of attaching apparatus. De Puytorac (1954) characterized $M$. lumbrici by 5-9 contractile vacuoles on each side; 84 dorsal and 71 ventral kineties, which were irregularly spaced (totaling 155 kineties). Paisán et al. (2009) described $M$. lumbrici from the intestine of Eisenia foetida, they reported that contractile vacuoles were 12 on each side, besides, 83 dorsal and 54 ventral kineties (totaling 137 ones).

Generally, the present ciliate possessed 4-6 as maximum contractile vacuoles on ciliate each side, 56-60 ventral and 75-84 dorsal kineties that totaled 131-144 kineties around the body. Heidenreich (1935) reported that the ectoplasmic fibers on the left half of $M$. lumbrici body originated ventrally along the left antero-lateral margin of the cell quite as if the missing left half of the inverted Vshaped apparatus was present. But, other fibers originated ventrally along right shaft of V-shaped apparatus, which was wellknown marked in the present species. On the other hand, Williams (1942) reported that the longest ventral ectoplasmic fibers of $M$. lumbrici were present on the central portion of the concavity and were shorten gradually on both sides. Also, he noted that fibers on the ciliate right side were finer than those on the left side. In present species, the longest ectoplasmic fibers were present on the ciliate left side decreased gradually in lengths toward extremity, besides, fibers on the ciliate right side, especially around the right shaft end were thicker than those on the left side.

M. heidenreichi differed from the pre-sent species in that right shaft of attachment apparatus exceeded $35 \mu \mathrm{m}$ in length (compared to $28 \mu \mathrm{m}$ in the present one). Besides, proximal end of spine was abruptly curved at right angle, enlarged with a rounded base for articulation with the right shaft of attaching apparatus. The last feature was not seen in the present ciliate where the spine was completely fused with the right shaft without evidence of any articulation or movement to spine detection during continuous studying of live specimens. De Puytorac (1954) described 58 ventral supporting ectoplasmic fibers in M. heidenreichi, with an asymmetrical arranged with the shortest fibers was present in latero-ventral side while longest ones were located in mid-ventral side and extended over almost the body length. In the present study, the fibers in mid-ventral side did not extended to body posterior region.

$M$. asymmetrica was described by Beers (1938) from Eisenia lonnbergii intestine. This ciliate was characterized by having only ventral ectoplasmic fibers supporting the attachment apparatus, restricted to the dep- 
ressed antero-ventral surface. He reported that all of supporting fibers (25-30 ones) originated from the right shaft and those on the left half of ciliate arise in the midline near the hook base and diverged slightly over the body posterior course. Also, Beers stated that a small area on the right side was devoid of fibers. In the present ciliate, 12-13 fibers originated ventrally from the ectoplasm left clear area; and the ventral fibers were directly developed along the extremity of right shaft without free-fiber area. The total number of kineties of $M$. asymmetrica was $100-120$ ones with an interval $1 \mu \mathrm{m}$, but the present one possessed 131-144 kineties. Williams (1942) described new species of Metaradiophrya, M. wenrichi from unidentified earthworm species. He reported that his species was very similar to $M$. lumbrici in general dimensions with the attachment apparatus morphometric data. On the other hand, he added that macronucleus was anteriorly curved strongly to right, sometimes; swell anteriorly so that the entire macronucleus resembled a spear. But, he neither gave details about kineties number, contractile vacuoles nor attachment apparatus-supporting fibers.

Away from the present ciliate size, many species of Metaradiophrya were described from Allolobophora sp. intestines; M. falcife $r a$ from A. caliginosa by Cépède (1910), De Puytorac (1954) and Rees (1961), M. hovassei from A. chlorotica and A. caliginosa by De Puytorac (1954) and Rees (1961) respectively, and M. gigas from A. savignyi by De Puytorac (1954). M. falcifera was characterized by a conspicuous torsion in the body anterior part to the right side, which resulted on the displacement of skeletal right shaft behind the anterior end of cell. Besides, ciliate possessed a large left skeletal branch; a homologue of skeletal left stem in M. varians, M. biflta and M. hovassei. By contrast, the present ciliate has an area of ectosarc on the spine left side, which have neither kineties nor skeletal elements. $M$. gigas was differrentiated than the present ciliate by its huge size, reached $550 \mu \mathrm{mx} 165 \mu \mathrm{m}, 10-12$ contractile vacuoles in each row and 137 ki-neties around the body.

\section{Conclusion}

In the present study, it is justified to consider Metaradiophrya a new species; Metaradiophrya egyptiaca characterized by moderate size, ventral ectoplasmic fibers restricted to antero-ventral depression with characteristic arrangement, without left skeletal element and low number of contractile vacuoles, 4-6 in each row.

\section{References}

Beers, CD 1938: Structure and division in the astomatous ciliate Metaradiophrya asymmetrica n. sp. J. Elisha. Mitchell. Sci. Soc. 54:111-25.

Bhandari, JC, Nikam, S, Kanse, VS, 2012: Report of new species of ciliate from the genus Metaradiophrya (Heidenrich, 1935) in Pheretima elongata from Aurangabad district (M.S.) India. J. Exp. Sci. 3, 5:5-7.

Cépède, C 1910: Recherches sur les infusoires astomes. Arch. Zool. Exp. Gén. 3:341-609.

Foissner, W 2014: An update of 'basic light and scanning electron microscopic methods for taxonomic studies of ciliated protozoa'. Int. J. Syst. Evol. Microbiol. 64:271-292.

Fokam, Z 2012: Etude morphologique et phylogénie des ciliés astomes endocommensaux d' Oligochètes terricoles de la région de Yaoundé et ses environs. Sciences du Vivant (q-bio). Université de Yaoundé I. Francais.

Fokam, Z, Ngassam, P, Strüder-Kypke, M C, Lynn, DH 2011: Genetic diversity and phylogenetic position of the subclass Astomatia (Ciliophora) based on a sampling of six genera from West African oligochaetes (Glossoscolecidae, Megascolecidae), including description of the new genus Paraclausilocola n. gen. Euro. J. Protistol. 47, 3:161-71.

Georgevitch, J 1941: Study on infusoria astomata of the Ochrida Lake oligochaeta (en serbe). Glasnik Srpske Kralj Akademije Belgrade 93:199.

Heidenrich, E 1935: Untersuchungen an parasitis chen ciliatenaus anneliden. Teil I: Systematik. Arch. F. Protistenk. 84:315-39.

Hovasse, R 1945: Endosymbiose bactérienne et astomie chez les ciliés. C.R. Acad. Sci. 221: $125-7$. 
Lynn, DH 2008: The Ciliated Protozoa: Characterization, Classification, and Guide to the Literature. $3^{\text {rd }}$ Edition.

Paisán, LE, Alonso, PQ, Alvarez, RSR, 2009: Descripción y primera mención en España de cuatro especies de ciliados endobiontes de Eisenia fetida (Savigny, 1826) (Annelida, Oligochaeta, Lumbricidae). Bol. R. Soc. Esp. Hist. Nat. Sec. Biol. 103, 1/4:37-47.
Rees, B 1961: Three British species of the genus Metaradiophrya including one new species M. gardneri. J. Parasitol. 51:227-32.

Pitelka, DR 2013: Ciliates. In: Electron-Microscopic Structure of Protozoa. Pergamum Press.

De Puytorac, P 1954: Contribution a l'etude cytologique et taxonomique des infusoires astomes. Ann. Sci. Natl. Zool. lime 16:85-90.

Williams, GW 1942: Observations on several species of Metaradiophrya (Protozoa: Ciliata). J. Morph. 70:545-98.

\section{Explanation of Figures}

Fig. 1: A- General morphology of the body. Rs: right shaft, Cs: Central spine, Ma: Macronucleus, Mi: Micronucleus, Cv: Contractile vacuoles. B- Synchronous waves of cilia strokes originated in lower right side of body as oblique waves. C- Arrangement of kineties around attaching apparatus. Ca: Clear area. D- Arrangement of ectoplasmic fibers around attaching apparatus (ventral side). E- Silver line system of ciliate. Ki: Kineties. F- Modes of movement of ciliate.

Fig. 2: A- General morphology. Black arrowhead: micronucleus, white arrowhead: contractile vacuole. Heidenhain's haematoxylin. B- Macronucleus exhibits a kind of spiral path along the longitudinal axis of ciliate. Heidenhain's haematoxylin. C- Kineties on dorsal side, narrowly spaced. D- Attaching apparatus of ciliate and its ectoplasmic fibers. Haematoxylin \& Eosin stain. E- Kineties on the ventral side of ciliate, note left kineties converge toward attaching apparatus. F- Enlarged view for antero-ventral area showing ectoplasmic fibers. Left black arrowhead: fibers on distal end of left shaft, right black arrowhead: longest fibers, white arrowhead: short fibers originate from extremity of left shaft 


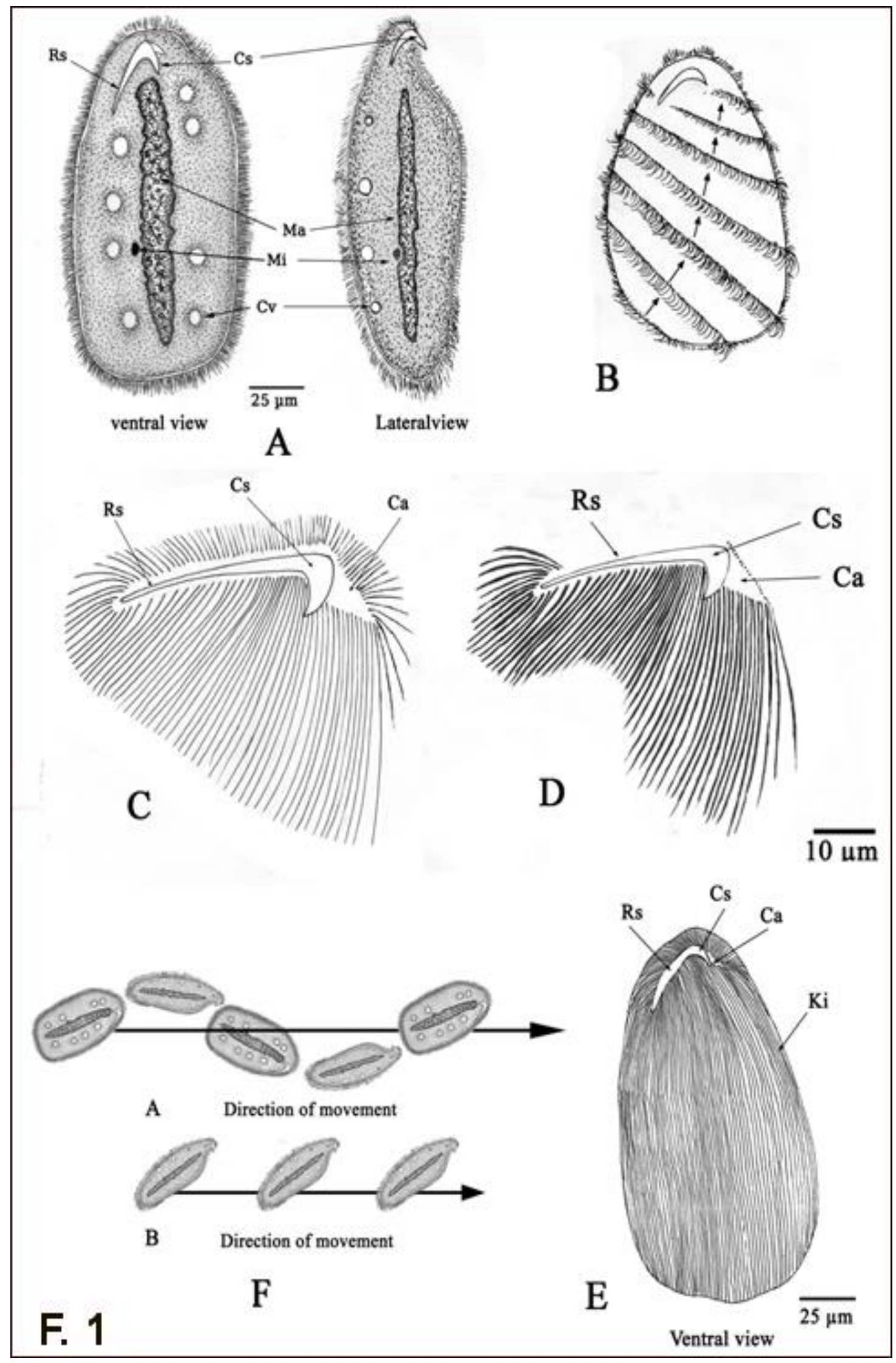




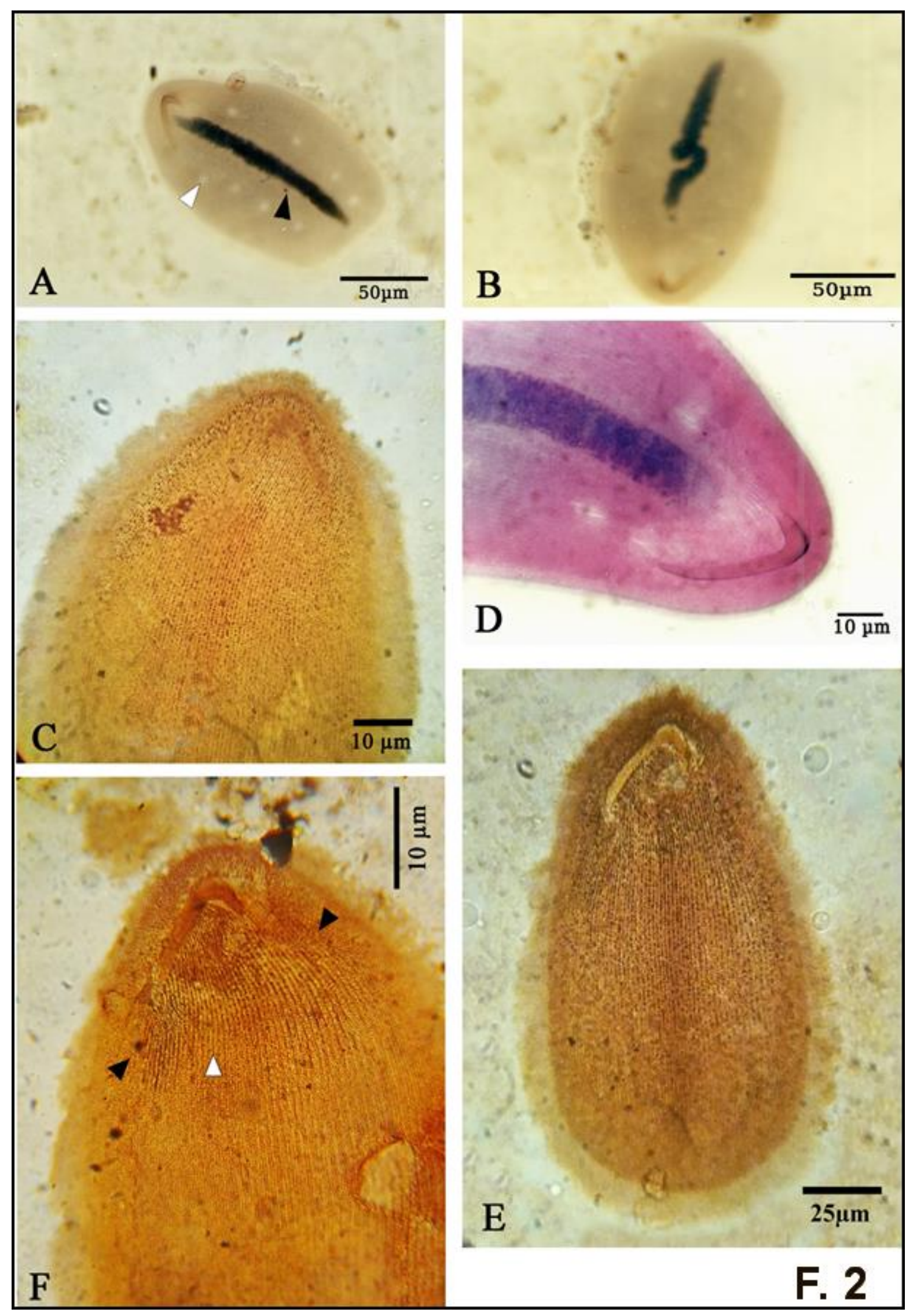

